\title{
The Radical Volte-Face of Place
}

Aritha van Herk

\section{OpenEdition}

\section{Journals}

Electronic version

URL: https://journals.openedition.org/ces/2141

DOI: $10.4000 /$ ces. 2141

ISSN: 2534-6695

\section{Publisher}

SEPC (Société d'études des pays du Commonwealth)

\section{Electronic reference}

Aritha van Herk, "The Radical Volte-Face of Place", Commonwealth Essays and Studies [Online], 42.2 I 2020, Online since 24 September 2020, connection on 27 January 2022. URL: http:// journals.openedition.org/ces/2141; DOl: https://doi.org/10.4000/ces.2141

This text was automatically generated on 27 January 2022

\section{(c) (i) (9)}

Commonwealth Essays and Studies is licensed under a Licence Creative Commons Attribution - Pas d'Utilisation Commerciale - Pas de Modification 4.0 International. 


\title{
The Radical Volte-Face of Place
}

\author{
Aritha van Herk
}

1 Elements of the place we call home tug through postcolonial thinking and writing, and the resonance of a past and a present that bespeak a future pulse in every word that we now deploy in any examination of place and its story - both verifiable and imaginary. While place seems to declare itself unambiguously, it also demands the vividness of complicated kinship, affinity, consanguinity, and entanglement. Critic Edward Relph says, "Our relationships with places are as necessary, varied, and sometimes perhaps just as unpleasant as our relationships with other people" $(1976,141)$. Certainly, those relationships to place and its story are intense and intimate and thorny. We respond to places with tactile perception, open to their textured, engrained, and attitudinal character, character that seeps between their chronicles and reputations. Cities bear their own imprimatur: London is seedily stately; New York is a temper tantrum in process; and Mexico City is an overcooked merengue - or do I mean meringue? Berlin is nervous; Los Angeles is narcissistic; and Amsterdam is tidily Calvinistic despite its licentious reputation. Calgary, Alberta, Canada, where I live, is peacefully tempestuous, prone to weather squalls and sundogs and sudden melts, hard winds and curtains of light so intense that the population wears a permanent squint. But a litany of cities cannot summarize the archaeology of place that haunts the literature of every place, and how it accommodates articulations and evasions.

2 As a writer, I reach toward continuing efforts to work within and without place. My own place-writing, my grief and my joy in the places that I know and that know me, and of course, my engagement with the idea of home, are an absorbing paradox. This is especially problematic, as the concept of being "from somewhere," recites an entitled expectation, and is inherently complicit with colonialism. Canada itself is a melange of gathered homes from elsewhere overprinted on the homes of Indigenous people. My parents, who were immigrants to Canada from the Netherlands, did not refer to their country of origin as "home," but as "the old country." That largely European allusion now means the country that a person came from, but to them meant the shedding of a story that had enmeshed them. The tone they used was sometimes regretful, sometimes scornful, and sometimes relieved; they did not yearn for "home," but yearned to belong in Canada. Their story was filled with conflict and hardship, an epic 
of confusion and danger and belligerence which confined them to a narrative arc that allowed too much history, too much sorrow, and too much elemental hostility. The story they embraced, the fragmented, unexpected welcoming story of Canada, promised an alternative outcome, a narrative less of prescribed paths than surprise and, even coded by hardship, the startle of start. A beginning, if not new. A starting over.

3 I revert to the origin of start, Old English, styrtan, meaning to caper or to leap, and its Dutch origin, storten, related to push, leap, or even dump (as in rubbish). Sudden movement or the beginning of a journey is the impetus here, a momentum relating well to the short story, especially the short story in relation to post-colonial fragmentation and replenishment. In the posthumous collection of her writings on writing, Startle and Illuminate, Carol Shields addresses the question of narrative that "makes its own shape, makes it up as it goes along, inventing and rearranging and pushing toward something new" as her impetus to "swerve away from the easy comfort zone of so-called epiphanies that accounted for the traditional rondure of short stories" $(2016,98)$. Shields models well the need to revisit and reinvent places, and how the inevitability of place nevertheless does not bypass disorder's attraction. Instead, she "wanted stories that soared off into mystery and disruption." Seeking to "dislocate the spine of a traditional story," she "observed how the human longing for disruption was swamped in fiction by an almost mechanical model of aesthetic safety" $(2016,99)$. That aesthetic safety is a version of "the old country" as inescapable home; while the refusal to shelter in its staticity becomes the terrain inconnu, the mutable space of place as process, and placelessness as illuminated destination. In this scenario, home performs a debatable role as crucibulum, not the current name for a bird's nest fungus, but medieval Latin, crucibulum as a night lamp to illuminate darkness, a vessel later repurposed as a melting pot for metals.

Shields identifies the desire of story as more than termination or resolution, "but a spiralling into space or a melting into another narrative as happens at the end of a story [she] wrote titled "Home"' $(2016,99)$. That story, which virtually transcends earth, proposes an interesting example of postcolonial suspension. It opens with one hundred people on a flight to London, at a time before jets, when propeller journeys across the Atlantic took twelve hours. Extraordinarily, the passengers experience together "a simultaneous sensation of joy" (Shields 2005, 182) that enables the aircraft's bright transcendence.

It must have been that the intensity and heat of this gathered happiness produced a sort of gas or ether or alchemic reaction [...] but for a moment, perhaps two, the walls of the aircraft, the entire fuselage and wings and tail section became translucent. The layers of steel, the rivets and bracing and ribwork turned first purple, then a pearly pink, and finally metamorphosed to the incandescence of pure light. (183)

Witnessed only by a twelve-year-old boy, "standing on a stony Greenland beach" (183), this transformation becomes his hoarded secret. The story makes no attempt to explain the phenomenon, but shifts to the boy who, as a man, years later, flies to Acapulco on vacation, and becomes himself part of a similar unusual vision to "Josephe, a young woman who works as a baggage checker behind the customs desk" (185). When she notices that every passenger stepping off the plane "is wearing blue jeans" (186), she is unnerved by "such statistical unanimity" (186): "she feels oddly assaulted by such totality, but the feeling quickly gives way to a head-shaking thrill of disbelief, then 
amusement, then satisfaction and, finally, awe" (186). The spiral of the story refuses revelation, and completely avoids the satisfaction of conclusion. Instead, the narrator simply observes that those who participate in extraordinary coincidences without knowing it remain "oblivious to the million invisible filaments of connection, trivial or profound, that bind them one to the other and to the small planet they call home" (186), with home as the resting place for the story. This disruption is achieved through a powerful coagulation of unanimity which nevertheless effects de Certeau's "common place" $(1984,1)$, or re-used as opportunity to subvert representation, thus enabling challenges to stability and propriety.

6 Shields' prismatic approach argues for the short story as a fragmented space, which nevertheless enables the "precision, dexterity, compression, and frugality" (Shields 2016, 102) of multiple opportunities for what Doreen Massey calls "the event of place" (2005, 149), its unpredictable contingency, its chance. That unsettling determines indeterminacy, and how home and place may themselves embody instability. In a recent work of poetry/memoir/fiction, a combined form that I would identify as placewriting entitled Dear Current Occupant, Vancouver writer Chelene Knight uses the notion of forensic fragmentation to re-trace the dissolving traces of her past. Moving with her mother from place to place in Vancouver, to some twenty or thirty different houses, often evicted, or sneaking off in the middle of the night, Knight as a child dreads her mother saying, without preamble: "Pack your things" (2018, 44). A complex response to the many different homes that Knight remembers and summons from her hardscrabble childhood, the text cracks open the idea of any coherent narrative achieving denouement. She declares:

The cracks in the narrative represent questions, untold truths, and illogical parts of a story. These are the events that would never make sense in a world with rules. The cracks in the narrative break the rules, there's a bending here too. I've been a crack in my own narrative for a long time. I didn't fit neatly into the story. (2018, 123)

Dear Current Occupant is a threnody, terrifying and beautiful, a labyrinth of making and unmaking the past. The persona seeks to discover what makes a house a home - not essential home, because she lived in multiple places of residence - and what made her what she is now, gathered out of a piecemeal earlier self. A mixed race Canadian "woman of colour" (Knight 2018, 118), Knight creates with this "memoir" a text that is both entirely hers and keenly aware of her difference. Dis-emplacement opens the cracks of placelessness within this study of place and, in the process, Knight herself becomes a place. "There were so many houses. Never mine, never ours. These houses carpets, floors, cupboards, missing closet doors, light bulbs, faucets, shelves, bathrooms, shower curtains, phone cords - constantly changing. Vancouver Eastside" (15). Throughout, in a torqued version of map-quest, the occupant of Dear Current Occupant searches for places she knew, insists that place inhabits those formative shapes that we carry in our bodies. "I went back to all of the houses mentioned in this book and stood out front shivering, gripping a pen and notebook in my hand. I took notes on anything and everything I could remember" (127). The urgency of remembering is coded into the trajectory of living the mercurial narrative of placement. Despite her writerly forage, Knight is unable to re-create places accurately. But in that vague penumbra of sensory and temporal occupation, from the emanation that we leave behind - a few flakes of dry skin, the one sock that was inadvertently abandoned under a couch, the scratches on the kitchen counter from using a knife 
without a board - places remember us. The Derridean notion of "trace" with its "nonsynonymic substitutions" (Kamuf 1991, 65) is at work here, as is the ghosting of ghosting and hauntology as a practice. Trace implicates place as a contingent term for remarking the absence of a presence. The language that we use for place "bears within itself the necessity of its own critique" (Derrida 2008, 216), and the destruction and construction of pure presence. As Mormei Zanke rightly asserts, "What Dear Current Occupant ultimately seeks to define is the presence, the concept of home" (2018). Few of us share the experience of Knight's traumatic childhood or her tattered security, how her sense of place was built out of movement and unsettlement. Ultimately, this autography builds itself out of the rubble of many places, conquering the void of placelessness to establish an individual sense of place within Knight's own body. She and her book - example the building of an ecology of imagination despite the absence of place. But beyond childhood, so formative in its power to articulate both imaginary and real places, I would argue that place re-places itself within its original encounter; desiring to recognize that replacement, we seek, in the autobiographical and the biographical, to measure and to reciprocate how we can build our narratives of place. Home we might take for granted, but must be less certain of, for an address does not necessarily signify any coherent story of home at all (as my linked stories about 11a Street in Calgary evince), precisely what Knight's book examines. The evocative aspect of invented autobiography, and autobiographical place, is that they both are intensely personal and utterly elusive.

Questions of place and the particular arise insistently. Place is redolently personal and always related to the self, despite the performance of, as Robert Kroetsch says, the "idea of self as a cosmic joke" (Neuman and Wilson 1982, 7). Characters in the narrative of time, embodiments of Julia Kristeva's “mosaic of quotations" $(1980,36)$, we are inscribed by multiple places in multiple ways - both determined and penumbral. These catch and release questions are the stuff of dreams and restlessness, a peripatetic participial living that performs in a circling assemblage between many different places, both enduring and discontinuous.

The unpredictability of human history and experience inflect place and personal geography in myriad ways. We do not live within "a set of hermetically sealed cultures with distinctive identities set in stone for all time" (Bonnemaison 2005, XVIII). "Space may be produced by society, yet society creates itself within a cultural space" (2), a sharp rejoinder to the dis-embedding that has come to ghost our contemporary social practices. We cannot claim, any longer, to be driven by the context of a restrictive origin in place and time (our ancestors moved far less frequently than we do) and yet, for all our experience, we enact a curiously blinkered awareness of place and time. We are, in this greedy, devouring moment, consuming place as much as we consume resources. We carry away mere impressions as if they were earned experiences although we must then ask, however hesitantly, where is the line between experience and impression? Are impossibly restless and constant temptations to pack and travel reflexes, or stigmata of effective branding? And with this habit - closer to addiction every visitation of place becomes another reading, a version of story reading its own inscription back to itself and becoming thus a thickened site of resistance inside creative expressions of where-ness.

Although some places are certainly more celebrated than others, every place claimed by short stories is further implicated in its own depiction. Witness, for example, Mavis 
Gallant's Paris Stories (2002) which are less about that city than about the secrets of expatriates who flânent in European streets, "too narrow for cars" (144). Paris serves as a ubiquitous setting for stories, as do New York and London and Berlin, in the endless literary domino of iteration. That exposure enables the duplication that engraves reputation. But representation escapes mimesis. I have been known to insist on the good qualities of the city of Calgary, Canada, which many would dispute, claiming that it is not a place but a post-modern city that was "uncrated yesterday," founded on a river of dirty oil money, and lacking a soul. For places to transcend their own depiction, it becomes necessary to engage with spaces specific but placeless for their sheer localism, intricate domesticity that becomes disruptive by its fractured performance of micro-place, a house, a street, a patch of yard, a rhubarb patch, a clothesline.

11 Place and geography perform together but are not fixed. Robert Kroetsch observes, "every journey across [geography] or through it is another reading" (Neuman and Wilson 1982, 8). And to cement that passage, "geography is people relating to [...] place" (9). Readers and writers alike yearn to see represented their experience of place, their experience in place: as more than a grey photograph floating against a blurred background. Can place-experiences be left where they are found? Can placeexperiences be re-found? Can location re-discover situations? Or does every inscription and its reading begin this placeless mapping over and over again? Ultimately, we must honour place, geography and people; in short, the story must be responsible to place, to "the nearness of place" (42) and the reader responsible for reading that place with all senses, beyond cause and effect.

Two years ago, my husband and I decided that we needed to plan for the future and renovate our home so that we can live there until we leave, "feet first," as the colloquial expression for dead would have it. I am not capable of living in mess and noise, so for more than a year we rented a little bungalow down in Calgary's Kensington neighbourhood, a district that used to be shabby and affordable, and now, because of its proximity to Calgary's downtown, has "gentrified" itself out of sight, at least in terms of property values, although it still pretends to be quaint and threadbare. That period of displacement and dis-embedding (it is disconcerting to "camp" in a temporary home that is smaller, older, and far less convenient than what one is accustomed to) became a source of place-fiction for me, and emerged in a series of stories under the umbrella "11a." The designation of the street comments on placelessness, resting as it does between $11^{\text {th }}$ and $12^{\text {th }}$ streets, and is thus measured as a half-street, not quite its own persona. The origin of this mathematical mapping is something of a mystery, although a historian could unpack its provenance, I am sure. But writing that street's placeness became for me a version of Sherwood Anderson's Winesburg, Ohio, and Faulkner's Oxford, Mississippi. The irony of those two towns being inventions of male American writers does not escape me; my analogy might be better made to Margaret Laurence's Manawaka or Alice Munro's Jubilee. Although not small town at all. 11a is a single street in a sharply discontented postmodern city, which suffers an ongoing and serious case of dismissive critique for its placeless character. Giving 11a stories rehabilitates the street as a place, although it does not have to become a place because it is already a place, an event, a place of enunciated space. I want, like Robert Kroetsch, to tell the "story of nothing to tell" (Neuman and Wilson 1982, 187) and in the process find the possibility of an "incredible web of story" (187). Tempted by place and story, wary of the extent to which my city is charged with soullessness, I enter the doorway of fiction, 
vocalized through a narrator who stands outside this "place" but is nevertheless part of its telling.

\section{$11 \mathrm{a}$}

The house is like a caboose at the tail end of the street, with a run of rooms that entrain one another east to west. When she showers, she has to run between the bathroom and the storage room to find her shampoo and hair products; she has wedged boxes and containers of her belongings into the tiny second bedroom, hoping she will not have to dig through them to find some essential article, although she inevitably does - the belt she needs for her linen pants, the scarf that matches her jacket. The bathroom is clearly an afterthought, the house's 1912 pantry converted to hold a splashy pedestal sink and a claw-footed wonder of a tub, with the toilet tucked inconveniently between, such a narrow aperture that her knees bruise the wall. She bashes her elbows every time she tries to dry herself off there, and the stone floor makes her toes curl, so she runs to the bedroom to dress, riffling through a dark closet to find a suitable sweater or tunic, and without perusing the clothes that she has stacked in plastic tubs, waiting for a better array of storage. She wears the same underwear over and over, the same tights, the same collection of shifts and trousers.

In this shaded street, sunrise barely raises light, for it sits in the hollow valley of the city, and the tree canopy wraps the house in a strange gloom. It has the feel of a cosy, dutiful cabin in the mountains, although it is as close to inner city as any house can be. She considers it a neutral house, dense and temporary, without a trace of anguish or threadbare misery, the tears that worked their way into the floorboards those of others, not her seepage. She has moved in, but determined not to stay, is camping on the hardwood stripes of the floor. At night, disturbed by the stealthy life out in the alley, she clings to the bed as if in a cabin on a tilting ocean liner.

The ghost at first disturbs her, but after a month, she grows accustomed to his insistence. His presence initially makes her leap out of her skin, for he bangs and clunks unexpectedly, a sound exactly like the thump of a great official stamp slamming down on a document, the way passport officers frank their approval. When she first hears it, she goes in search of the cause of the noise, the intruder who must have slammed some cupboard door down in the dug-out basement. Nothing. And so, with the help of a local historian, she discovers that the house was first built by a land titles man (irony abounds) who lived and worked here. In the front room of this caboose-like framed house he documented purchases and measurements, the dividing up of raw land into parcels and lots. In the early 1900s, this area was a new settlement, simply described as "scattered wooden dwellings" surrounded by gardens. Now it epitomizes density, huddled on the north side of the river, just across the bridge from the place that began as a Mountie post and a railway depot and has now turned itself into a forest of towers, yearning toward a sky endless with light, and haunted by the many stories cemented over, including traces of the Indigenous people who lived here longer than anyone.

Her surveyor jostles her in the front hall when she is putting on her shoes to go out; in his life he came and went often, a busy man, bustling and efficient. He finds her kitchen arrangement unsatisfactory; and moves her cups around - nothing but cups, as if drinking her coffee. She's come to expect his ghostly brushes, although she hasn't yet 
begun to talk to him. She is relieved that he is a friendly ghost and does not seem to mind her presence, although she worries that he could turn if she outstays her welcome. But they grow accustomed to one another and sail the street together, through its seasons.

Stories circulate most in autumn. That time of year 11a is rife with rumour, with murmurs and gasps, with the fall-out of a long hot summer overtaken by boredom and bad behaviour. The residents on 11a live the same recitals as anywhere in the world, but they have not been practiced exactly as they happen here, on this crooked-backed street with its open-faced houses. 11a creates its own mythology of place, and if that requires some exaggeration, well, let the plot unfold, let the gambits take themselves in new directions, let the affairs and the rumours of affairs feed the cracks in the sidewalk, the potholes in the alley. For they do proliferate.

Autumn is when places change their shape, when they encounter skeletons and buried pasts, the branches of trees, the dying stalks of plants. The face of 11a transforms itself to a less ardent place, no longer a bower of branches, but lined with blowing dust, windier, angrier. Doors propped open over the summer are now firmly shut, and a greyness overcasts what should be a golden time, a cliché of crisp leaves and beautiful air. The crab-apple trees, so blowzily enticing in the spring, are now dropping brown apples which the crows peck at voraciously, and bohemian waxwings circle, drunk on fermented mountain ash berries. The street begins to prepare for the coming of darkness, becomes a place more provisional, as if prepared to change its name. 11a once had a different name, a person's name, Preston Street. No one remembers who Preston was, and whether they - probably a "he" - was significant or not. People assume that it is the name of one of the long-lost NWMP men who first dragged themselves into the area, pretending to authority, belligerent and hungry, but that can't be proven. Preston might or might not have been a Mountie. More likely he was a remittance man.

But 11a is fond of its idiosyncrasy - that it was an extra street created out of long yards, located between $11^{\text {th }}$ and $12^{\text {th }}$ streets, a once-alley turned into a half street. Only one other street in Hillhurst, 10a, enjoys that long division. For that reason, the characters who live on 11a know their exception. Their mental map of the street, their neighbours, their friends, the feeling of each hedged front yard inhabits them. Were you to inquire about the intrinsic knowledge of spatial cognition, Walton the schoolteacher would offer a long-winded answer that would involve "afferent inputs," and cells in the entorhinal cortex. You would zone out from his over-detailed lecture, into private pathways and plans. But he is right, that part of the brain works with memory and navigation, and every one of the denizens of 11a could map this street in detail, could connect dwelling place with dwelling place: who lives in each house, along with how they live, whether they sweep the sidewalk or simply spray a hose over it, whether they edge their lawns or let the grass creep over the lip of the sidewalk. Place cells do emplace everyone, certainly, but for the residents they are particularly acute, for 11a manages to be both temporary and permanent, desirable and plain, secret and obvious. It is that kind of street in that kind of city, a street with a history and a future, a present almost incongruous in a city where buildings vanish without a trace, and then re-appear where they are least expected. As a subset, 11a could be picked up and dropped in the middle of a small mid-western town. Or it could be elevated to a movie set, so wildly and improbably retro it lies about its own over-pleasant profile. And the 
characters who live on 11a still feel as if, living there, they are caught between lost and found.

Anja, a student of archeology who rents an illegal downstairs suite in a crumbling brick three story in the middle of the block, is troubled by 11a's placidity. She has just spent a month in Croatia, in Zadar, that glorious city on the shore of the Adriatic. There, she found a small flat on Rudera Boskovica, less a flat than a crazy jumble of rooms overlooking the red-tiled roofs that layer the city. Her favourite restaurant she reaches by circling past the ruins of the old Roman forum, downing in one shot the welcome drink of Rakija, then ducking through a doorway set in the wall into a garden, where in warm weather, people sit to enjoy their beer and to talk about the fishing in the Adriatic. She prefers the inner cellar room, stone-lined, dusky.

On her fourth visit, the waitress begins to grow used to her. "You stay here?"

"Yes," she says. "For a while."

When the woman brings her fish and blitva, she asks, "How old is this cellar?"

The waitress shrugs. "Old. It was the bakery for the monastery for centuries."

"The monastery?"

"Yes, Franciscans. Everyone came to buy bread. We still use the ovens. They survived the last war, so they will last forever."

"How old?"

"They say the bakery goes back to Venetians. So many peoples. Romans, Venetians, Germans, Italians. Look at the walls."

Anja peers at them more carefully. "Different shapes."

"Yes. Places fall. Places bombed. We take a stone from there, fit them into the holes, repair."

"But what if they are ancient?"

The waitress shrugs. "We see a stone, we use it. Here are Roman stones, Byzantine stones. Together."

"But the ruins?" Anja is shocked by this casual dismissal of archeological treasure.

"A stone is a stone. Only good for what it can do, repair."

It is true. The different textures embedded in the walls there in the hollow little restaurant speak to their practical gathering, porous memories now inducted to another use. This pragmatism is visible all over the coastal city, the melange of past occupations and hostilities, Zadar once a jewel shiny as Venice. The entrainment of Zadar is its own meta-text, a series of fictions and facts piled on top of one another, resistance and tolerance until now it has morphed into a day-stop for cruise ships, releasing lines of duckling tourists marched along the Riva by umbrella-thrusting guides.

Anja has come to escape the parochial intensity of her own narrow street in her unremarkable city, a city which lacks archeology or history, but assumes that it belongs where it belongs, there on the banks of the Bow, refusing to remember the earlier shape of the land that it has re-shaped. She has trouble accommodating Croatian functionalism, and so instead of taking notes on the ancient criss-crossed civilizations that she journeyed to the Adriatic to investigate, she finds herself wandering the sly and crooked streets, taking photographs of laundry. The intricate semaphore of drying clothes flutters universal; in every world, lines of laundry signature dwelling and circumstance, offer refuge from depletion and bereavement and the damnable inescapability of history. She avoids her research and instead focusses on her own 
laundry story, its many iterations, the clothesline aperture that opens above the courtyard below, the women in the apartments hanging out shirts and underwear, leaning into the open space of air. They shout when they drop a piece of laundry, and then thump down the stairs to the courtyard to find the item, now needing to be rewashed.

Anja remembers her own immature city, and one of its earliest portrayals, a drawing of the place from 1876, attributed to a mutton-chopped Superintendent William Winder of the North-West Mounted Police. It is a depiction of the fort and the river, both looking historical and important; but in the foreground a Métis woman bends over a washtub, and stretched from a tripod, a line of laundry hangs in a phrenology of personalism and daily, quotidian survival. Anja thinks of how re-arranged stones argue between the past and the present, trace and breath. Useful, actual, not merely seen but present, persistent, they speak the volte-face of place. In the catoptric of metropolitan change, she straddles stone, old stones and new, the ephemeral and the doggedly eternal, while between them, a line of laundry flags the life of individuals, how ovens continue to bake bread, and how we all live within the spatial compression of capacious stories.

Even if we think we can escape place, it refuses to release us.

\section{BIBLIOGRAPHY}

BONNEMAISON, Joël. 2005. Culture and Space: Conceiving a New Cultural Geography, edited by Chantal Blanc-Pamard, Maud Lasseur and Christel Thibault. Translated by Josée Pénot-Demetry. London: I.B. Tauris. Originally published as La géographie culturelle (Paris: Editions du CTHS, 2000, 2004). DE CERTEAU, Michel. 1984. The Practice of Everyday Life. Translated by Steven Rendall. Berkeley: University of California Press. Originally published as L'Invention du quotidien (Paris: Gallimard, 1980).

DERRIDA, Jacques. 2008. "Structure, Sign and Play in the Discourse of the Human Sciences." Translated by Alan Bass, 1978. In Modern Criticism and Theory: A Reader, edited by Nigel Wood and David Lodge, 210-24. London: Routledge. Originally published in L'écriture et la difference (Paris: Seuil, 1967).

GALLANT, Mavis. 2002. Paris Stories. Toronto: Penguin.

KAMUf, Peggy. 1981. A Derrida Reader: Between the Blinds. New York: Columbia University Press. KNIGHT, Chelene. 2018. Dear Current Occupant. Vancouver: Bug*hug.

KRISTEVA, Julia. 1980. “Word, Dialogue, and Novel.” In Desire in Language: A Semiotic Approach to Literature and Art, edited by Leon S. Roudiez. Translated by Thomas Gora, Alice Jardine, and Leon S. Roudiez. New York: Columbia University Press.

MASSEY, Doreen. 2005. For Space. London: Sage Publications.

NEUMAN, Shirley, and Robert WILSON. 1982. Labyrinths of Voice: Conversations with Robert Kroetsch. Edmonton: NeWest Press. 
RELPH, Edward. 2008. Place and Placelessness. 1976. London: Pion.

SHIELDS, Carol. 2005. The Collected Stories. Toronto: Vintage Canada.

SHIELDS, Carol. 2016. Startle and Illuminate: Carol Shields on Writing. Toronto: Random House.

ZANKE, Mormei. 2018. "Redefining Home: a Review of Chelene Knight's Dear Current Occupant."

Prism Online, Prism International. 5 July. https://prismmagazine.ca/2018/07/05/redefining-home-

a-review-of-chelene-knights-dear-current-occupant/.

\section{ABSTRACTS}

This critical exploration and the accompanying meta-fictional narrative explore the impetus of how place inspires, despite its inherent truancy of expectation, an articulated desire, a longing or initiation of not-quite memory and its placeless intensity. How do stories of the past of place teach us a way to write story about and within place, to embark on the epistemological anxiety of writing what is ordinary, and thus remarkable. The essay addresses strategies of evasion that writing place enables in worlds that negotiate concealed history. By exploring interstitial space when dwelling place and circumstance together insist on inscribing past inhabitants, place reflects its reflectors.

\section{INDEX}

Keywords: home, placelessness, Carol Shields, Chelene Knight, Calgary

\section{AUTHOR}

\section{ARITHA VAN HERK}

University of Calgary

Aritha van Herk is the author of five novels, two books of criticism, and many non-fiction and ficto-critical texts, especially works that develop the idea of geographical and historical temperament as tonal accompaniment to landscape. She has published myriad articles, reviews and essays on Canadian culture. She teaches literature and Creative Writing in the Department of English at the University of Calgary in Alberta. 